\title{
Bio-chemical Constituents, Value Addition and Alternative Uses of Colocasia (Colocasia esculenta L.)
}

\section{K Laxminarayana*}

Regional Centre, Central Tuber Crops Research Institute, Dumuduma, Bhubaneswar, Orissa, India

*Corresponding Author: K Laxminarayana, Regional Centre, Central Tuber Crops Research Institute, Dumuduma, Bhubaneswar, Orissa, India.

DOI: $10.31080 /$ ASAG.2020.04.0819
Received: January 08, 2020

Published: February 29, 2020

(C) All rights are reserved by $\mathbf{K}$

Laxminarayana.

\begin{abstract}
Taro (Colocasia esculenta) is a tropical food crop with high potential, widely adapted to varied agro-climatic conditions. Colocasia contain $3.7-3.9,1.16-1.53,21.7-24.4 \mathrm{~g} / 100 \mathrm{~g}$ of crude protein, crude fibre, carbohydrates, respectively and minerals to an extent of $382-1049,114-171,0.19-0.51,3.24-11.72,3.01-5.63,0.54-6.82,58-266,78-96$, and $8.4-39.6 \mathrm{mg} / 100 \mathrm{~g}$ of potassium, phosphorus, copper, iron, zinc, manganese, calcium, magnesium, and sodium, respectively. Presence of fairly good amount of phytochemicals and antioxidants in colocasia had been proven effective in controlling coronary heart diseases, certain cancers and chronic degenerative diseases. Taro leaf silage, petioles, and corms could be used as feed ingredients for rearing of pigs, ducks and poultry. Keywords: Colocasia; Minerals; Proximate Composition; Value Addition
\end{abstract}

\section{Introduction}

Edible aroids (family Araceae) comprise of many underground food crops grown in several tropical and sub-tropical countries. Taro or colocasia or cocoyam (Colocasia esculenta) is a tropical food crop with high potential because of the high yield of the roots (or corms) and foliage. The leaves are rich in protein and easy to ensile to reduce the concentrations of calcium oxalate, which appears to be a limiting factor in consumption of the fresh leaves [10]. Worldwide it grows in an area of $1.66 \mathrm{Mha}$ with a production of $10.64 \mathrm{Mt}$ and productivity of $6.41 \mathrm{t} \mathrm{ha}^{-1}$ [13]. It is extensively cultivated in Nigeria with a production of $3.30 \mathrm{Mt}$, China (1.95Mt), Cameroon (1.90 Mt) and Ghana (1.46 Mt). It is extensively cultivated in Africa (1.468 Mha) by producing 7.87 Mt with a productivity of $5.36 \mathrm{t}$ ha 1 , however, it grows fairly in lesser area (0.138 Mha) in Asia with a production of $2.31 \mathrm{Mt}$ and productivity of $16.79 \mathrm{t} \mathrm{ha}^{-1}$, but the Egypt, Japan and U.S. recorded 35.96, 12.50 and 11.26 and $t$ ha $^{-1}$, respectively. Yields in Pacific island countries ranged from $19.99 \mathrm{t}$ $\mathrm{ha}^{-1}$ for Fiji to about $7.69 \mathrm{t} \mathrm{ha}^{-1}$ for Papua New Guinea. Cultivation of taro is widespread in India, Burma, China, Japan, Hawaii, Egypt, Africa and the Caribbean. Worldwide taro imports revealed that Japan has imported worth of US\$ 43.4 followed by United States US\$ 36.3. Australia and New Zealand are the two major destinations for Pacific taro exports.

Phytochemicals and antioxidant constituents in plant materials have raised interest among scientists, food manufacturers, producers, and consumers for their roles in the maintenance of human health [32]. Cocoyam is nutritionally rich in carbohydrates, minerals, vitamins and other phytochemicals. However, its composition varies according to the variety and country of origin. Numerous epidemiological studies suggest that diets rich in phytochemicals and antioxidants execute a protective role in health and diseases. Frequent consumption of fruits and vegetables is associated with a lowered risk of cancer, heart disease, hypertension and stroke $[30,55,56]$. Phytochemicals are bioactive substances of plants that have been associated in the protection of human health against chronic degenerative diseases. Antioxidants are compounds that help delay and inhibit lipid oxidation and when added to foods tend to minimize rancidity, retard the formation of toxic oxidation products, help maintain the nutritional quality and increase their shelf life [16].

Taro leaf silage could replace up to $70-75 \%$ of the fish meal protein, with higher feed intake and $\mathrm{N}$ retention than with $100 \%$ of the protein from fish meal or from taro leaf silage [10]. The mature corms and young shoots of aroids are mostly used as boiled vegetables, but the corms are roasted, baked, or fried and can be eaten alone or with stew. In parts of West Africa, the boiled corms are mashed and used as weaning diet. The flour of mature corms used to prepare 'fufu' that is commonly eaten in Nigeria with stew. In southeastern parts of Nigeria, tannia is used in small quantity as soup thickener after boiling and pounding to obtain a consistent paste. Taro chips is another important secondary product. In the South Pacific, young taro leaves are used with coconut cream to prepare a dish called 'luau', which is used to eat the boiled or roasted taro, breadfruit and banana.

The corms supply easily digestible starch and are known to contain substantial amounts of protein, vitamin C, thiamine, riboflavin, niacin and significant amounts of dietary fiber [34]. Leaves of taro are cooked and eaten as vegetable. They contain $\beta$-carotene, iron and folic acid, which protects against anemia and are important 
source of proteins and vitamins [51]. The main nutrients supplied by taro, as with other roots and tubers, is dietary energy provided by the carbohydrates. Cocoyam flour can be used for the preparation of soups, biscuits, bread, beverages, and puddings. Research and development of root and tuber crops in general, and cocoyam in particular, have been neglected because only $10 \%$ of the world populations, mainly in the developing tropical countries, use root and tuber crops as staple foods. In view of its phytochemical composition and diversified uses, it is very essential to popularize cocoyam among the manufacturers and various clientele groups for effective utilization and large scale cultivation in the potential areas. Opportunities to promote and support the use of cocoyam can make a major contribution to the food security of the people. Since the cultivation of taro is being concentrated globally due to its diversified uses, the present review is aimed to make awareness about the biochemical constituents, and value addition of colocasia among the various clientele groups for its wide cultivation towards the income generation, livelihood and nutritional security.

\section{Bio-chemical constituents}

Edible aroids have a higher content of protein and amino acids than many other tropical root crops [8]. The nutritional and chemical composition of taro roots are presented in table 1 . The nutritional values of major edible aroids are presented in table 2 and 3. Colocasia contain 68 - 70, 3.7 - 3.9, 1.16 - 1.53, 21.7 - 24.4 g/100g of moisture, crude protein, crude fibre, carbohydrates, respectively. It also contain minerals to an extent of $382-1049,114-171,0.19$ - $0.51,3.24-11.72,3.01-5.63,0.54-6.82,58-266,78-96$, and 8.4 - $39.6 \mathrm{mg} / 100 \mathrm{~g}$ of potassium, phosphorus, copper, iron, zinc, manganese, calcium, magnesium, and sodium, respectively. A summary of comprehensive chemical analysis of aroids from different countries is also presented in table 4 . The purpose of these data is to assist food process engineers and many other scientists in developing improved food processing operations as well as new food products, particularly those aimed at enhancing the nutritional status of people living in regions that produce cocoyams. Considering the huge variation in compositional data of raw material in general, these data must be used only as a guide in making nutritional calculations.

The major groups of phytochemicals that may contribute to the total antioxidant capacity (TAC) of plant foods include polyphenols, carotenoids and the traditional antioxidant vitamins such as vitamin C and vitamin E. The vitamins are, however, not the only phytochemicals that can have a positive effect on the health of consumers. The leaves of colocasia contain total antioxidant capacity, and total polyphenol contents of 130 and $120 \mathrm{mg} / 100 \mathrm{~g}$, respectively. Considerable amount of carotenoids and flavonols were also detected in the colocasia leaves. The TAC assay is a convenient way of assessing the total antioxidant level in foods (Table 5) and was used to determine the amount of the collective antioxidant activity in a given food [17]. Total polyphenol (TPP) and total anthocyanin (TAT) content are also good indicators of antioxidant capacity and studies have reported a high correlation between antioxidant capacity and total polyphenols [40].

\begin{tabular}{|l|c|c|}
\hline \multicolumn{1}{|c|}{$\begin{array}{c}\text { Principle/ } \\
\text { Vitamins }\end{array}$} & $\begin{array}{c}\text { Nutrient value per } \\
\mathbf{1 0 0} \mathbf{g}\end{array}$ & $\begin{array}{c}\text { Percentage of } \\
\text { RDA }\end{array}$ \\
\hline Energy & $112 \mathrm{Kcal}$ & $6 \%$ \\
\hline Carbohydrates & $26.46 \mathrm{~g}$ & $20 \%$ \\
\hline Protein & $1.50 \mathrm{~g}$ & $3 \%$ \\
\hline Total fat & $0.20 \mathrm{~g}$ & $<1 \%$ \\
\hline Cholesterol & $0 \mathrm{mg}$ & $0 \%$ \\
\hline Dietary Fiber & $4.1 \mathrm{~g}$ & $11 \%$ \\
\hline Folate $\left.\mathrm{B}_{9}\right)$ & $22 \boldsymbol{\mu g}$ & $5.5 \%$ \\
\hline Niacin $\left.\mathrm{B}_{3}\right)$ & $0.600 \mathrm{mg}$ & $4 \%$ \\
\hline Pantothenic acid & $0.303 \mathrm{mg}$ & $6 \%$ \\
$\left(\mathrm{~B}_{5}\right)$ & & $23 \%$ \\
\hline Pyridoxine $\left(\mathrm{B}_{6}\right)$ & $0.283 \mathrm{mg}$ & $2 \%$ \\
\hline Riboflavin $\left(\mathrm{B}_{2}\right)$ & $0.025 \mathrm{mg}$ & $8 \%$ \\
\hline Thiamin $\left(\mathrm{B}_{1}\right)$ & $0.095 \mathrm{mg}$ & \\
\hline Vitamins $/$ Electrolytes/ Phyto-nutrients & \\
\hline Vitamin $\mathrm{A}$ & $76 \mathrm{IU}$ & $2.5 \%$ \\
\hline Vitamin $\mathrm{C}$ & $4.5 \mathrm{mg}$ & $7 \%$ \\
\hline Vitamin $\mathrm{E}$ & $2.38 \mathrm{mg}$ & $20 \%$ \\
\hline Vitamin $\mathrm{K}$ & $1 \boldsymbol{\mu g}$ & $1 \%$ \\
\hline Sodium & $11 \mathrm{mg}$ & $<1 \%$ \\
\hline Potassium & $591 \mathrm{mg}$ & $12.5 \%$ \\
\hline Calcium & $43 \mathrm{mg}$ & $4 \%$ \\
\hline Magnesium & $33 \mathrm{mg}$ & $8 \%$ \\
\hline Copper & $0.172 \mathrm{mg}$ & $19 \%$ \\
\hline Iron & $0.55 \mathrm{mg}$ & $7 \%$ \\
\hline Zinc & $0.23 \mathrm{mg}$ & $2 \%$ \\
\hline Manganese & $0.383 \mathrm{mg}$ & $1.5 \%$ \\
\hline Carotene- $\boldsymbol{\beta}$ & $35 \boldsymbol{\mu g}$ & -- \\
\hline Cryptoxanthin- $\boldsymbol{\beta}$ & $20 \boldsymbol{\mu g}$ & \\
\hline
\end{tabular}

Table 1: Bio-chemical constituents in taro roots.

\begin{tabular}{|c|c|c|c|c|c|c|}
\hline \multirow{2}{*}{$\begin{array}{c}\text { Constituent/ } \\
\text { Major nutrients }\end{array}$} & \multicolumn{3}{|c|}{$\begin{array}{l}\text { Taro (Colocasia } \\
\text { esculenta) }\end{array}$} & \multicolumn{3}{|c|}{$\begin{array}{c}\text { Tannia (Xanthosoma } \\
\text { sagittifolium) }\end{array}$} \\
\hline & Corms & Leaves & \begin{tabular}{|c|} 
Leaf \\
stalks
\end{tabular} & Corms & Leaves & Shoots \\
\hline \begin{tabular}{|l|} 
Calories \\
\end{tabular} & 102 & 94 & 24 & 133 & 34 & 33 \\
\hline Protein (g) & 1.8 & 202 & 0.5 & 2.0 & 2.5 & 3.1 \\
\hline Fat (g) & 0.1 & 0.4 & 0.2 & 0.3 & 1.6 & 0.6 \\
\hline Carbohydrate (g) & 23 & 21 & 6 & 31 & 5 & 5 \\
\hline Fibre (g) & 1.0 & 0.8 & 0.9 & 1.0 & 2.1 & 3.2 \\
\hline Calcium (mg) & 51 & 34 & 49 & 20 & 95 & 49 \\
\hline $\begin{array}{l}\text { Phosphorous } \\
\text { (mg) }\end{array}$ & 88 & 62 & 25 & 47 & 388 & 80 \\
\hline Iron (mg) & 1.2 & 1.2 & 0.9 & 1.0 & 2.0 & 0.3 \\
\hline
\end{tabular}

Vitamins

\begin{tabular}{|l|c|c|c|c|c|c|}
\hline $\begin{array}{l}\text { B-carotene equiv. } \\
(\mu \mathrm{g})\end{array}$ & trace & trace & 180 & trace & 3300 & - \\
\hline Thiamine $(\mathrm{mg})$ & 0.10 & 0.12 & 0.02 & 0.10 & - & - \\
\hline Riboflavin (mg) & 0.03 & 0.04 & 0.04 & 0.03 & - & - \\
\hline Niacin (mg) & 0.8 & 1.0 & 0.4 & 0.5 & - & - \\
\hline $\begin{array}{l}\text { Ascorbic acid } \\
(\mathrm{mg})\end{array}$ & 8 & 8 & 13 & 10 & 37 & 82 \\
\hline
\end{tabular}

Table 2: Nutritional content of the major edible aroids per $100 \mathrm{~g}$ edible portion. 


\begin{tabular}{|l|l|}
\hline \multicolumn{1}{|c|}{ Edible aroid } & \multicolumn{1}{c|}{ Nutritional and chemical composition } \\
\hline Taro (Colocasia esculenta) & $\begin{array}{l}\text { Middle range energy, protein and vitamins, high K and Zn, low Na, medium trypsin inhibitor; } \\
\text { some cultivars acrid. }\end{array}$ \\
\hline Tannia (Xanthosoma spp) & $\begin{array}{l}\text { Like taro, but high in nicotinic acid, lowest in free Ca (zero) and low trypsin inhibitor; some } \\
\text { cultivars acrid. }\end{array}$ \\
\hline $\begin{array}{l}\text { Giant taro (Alocasia spp.) } \\
\text { Middle range energy, highest protein, lowest -carotene (zero), thiamine and riboflavin, high Fe } \\
\text { and Mn, low K and Cu, very large amount of trypsin/chymotrypsin inhibitor; acrid. }\end{array}$ \\
\hline $\begin{array}{l}\text { chamissonis) } \\
\text { campanulatus) }\end{array}$ & $\begin{array}{l}\text { Low energy and protein, high dietary fibre, low vitamins, high Na, Zn and Mn, very low K, large } \\
\text { amount of total oxalate and calcium oxalate; some acridity. }\end{array}$ \\
\hline
\end{tabular}

Table 3: Nutritional and chemical characteristics of main edible aroids.

\begin{tabular}{|c|c|c|c|c|}
\hline \multirow{2}{*}{ Number of samples and countries } & Tannia & Giant taro & Giant swamp taro & Elephant foot yam \\
\hline & $\begin{array}{c}71 \text { samples from } 3 \\
\text { countries }\end{array}$ & $\begin{array}{c}37 \text { samples from } 2 \\
\text { countries }\end{array}$ & $\begin{array}{c}37 \text { samples from } 2 \\
\text { countries }\end{array}$ & $\begin{array}{c}27 \text { samples from } 2 \\
\text { countries }\end{array}$ \\
\hline Moisture (\%) & 69.1 & 67.1 & 70.3 & 75.4 \\
\hline Energy $\left(\mathrm{kJ} .100 \mathrm{~g}^{-1}\right)$ & 480 & 521 & 449 & 348 \\
\hline Protein (\%) & 1.12 & 1.55 & 2.15 & 0.51 \\
\hline Starch (\%) & 24.5 & 27.6 & 21.5 & 16.8 \\
\hline Sugar (\%) & 1.01 & 0.42 & 0.96 & 1.03 \\
\hline Dietary fibre (\%) & 1.46 & 0.99 & 1.85 & 2.78 \\
\hline Fat (\%) & 0.10 & 0.11 & 0.10 & 0.16 \\
\hline Ash (\%) & 0.87 & 1.04 & 0.92 & 0.67 \\
\hline \multicolumn{5}{|l|}{ Minerals (mg $100 \mathrm{~g}^{-1}$ ) } \\
\hline Calcium (Ca) & 32 & 8.5 & 38 & 182 \\
\hline Phosphorus (P) & 70 & 53 & 44 & 16 \\
\hline Magnesium (Mg) & 115 & 27 & 52 & 21 \\
\hline Sodium (Na) & 1.8 & 6.6 & 30 & 72 \\
\hline Potassium (K) & 448 & 530 & 267 & 67 \\
\hline Sulphur (S) & 8.5 & 7.9 & 12 & 3.3 \\
\hline Iron $(\mathrm{Fe})$ & 0.43 & 0.40 & 0.83 & 0.61 \\
\hline Copper $(\mathrm{Cu})$ & 0.18 & 0.19 & 0.07 & 0.11 \\
\hline Zinc (Zn) & 3.8 & 0.52 & 1.57 & 2.3 \\
\hline Manganese (Mn) & 0.35 & 0.17 & 0.62 & 0.69 \\
\hline Aluminium (Al) & 0.38 & 0.53 & 0.36 & 1.36 \\
\hline Born (B) & 0.09 & 0.09 & 0.10 & 0.09 \\
\hline \multicolumn{5}{|l|}{ Vitamins (mg $100 \mathrm{~g}^{-1}$ ) } \\
\hline Vit. A (ret. + -car./6) & 0.007 & 0.005 & 0 & 0.005 \\
\hline Thiamin & 0.032 & 0.024 & 0.021 & 0.025 \\
\hline Riboflavin & 0.025 & 0.032 & 0.018 & 0.019 \\
\hline Nicotinic acid & 0.76 & 0.80 & 0.48 & 0.46 \\
\hline Pot. Nic. Acid $=$ Trp $/ 60$ & 0.19 & 0.33 & 0.46 & 0.07 \\
\hline Total vitamin $\mathrm{C}(\mathrm{AA}+\mathrm{DAA})$ & 15 & 14 & 17 & 16 \\
\hline \multicolumn{5}{|c|}{ Organic acid anions and calcium oxalate (mg $100 \mathrm{~g}^{-1}$ ) } \\
\hline Total oxalate (Ox) & 65 & 42 & 42 & 288 \\
\hline Soluble oxalate & 35 & 44 & 17 & 45 \\
\hline Calcium oxalate & 43 & 23 & 37 & 399 \\
\hline Free calcium & 10 & 0 & 15 & 10 \\
\hline Malate & 107 & 211 & 320 & 106 \\
\hline Citrate & 102 & 314 & 278 & 86 \\
\hline Succinate & 168 & 506 & 370 & 295 \\
\hline Trypsin inhibitor (TIU g ${ }^{-1}$ ) & 14 & 0.3 & 269 & 2.5 \\
\hline Chymotrypsin inhibitor $\left(\mathrm{CIU} \mathrm{g}^{-1}\right)$ & 0 & 0 & 57 & 0 \\
\hline
\end{tabular}

Table 4: Nutritional and chemical composition of different varieties of edible aroids from different countries. 


\begin{tabular}{|l|c|c|c|c|c|c|c|c|}
\hline \multicolumn{1}{|c|}{ Vegetable } & $\begin{array}{c}\text { TAC } \\
\text { (mg/100g) }\end{array}$ & TPP & Myricetin & Fisetin & Quercetin & Kaempferol & $\alpha$-Carotene & $\beta$-Carotene \\
\hline Sweet potato (Orange) & 770 & 260 & 26 & 7 & 78 & 3 & 0.76 & 86 \\
\hline Sweet potato (Composite) & 650 & 270 & 24 & 7 & 90 & 8 & 2.1 & 13 \\
\hline Moringa & 260 & 260 & nd & nd & 100 & 34 & 4.5 & 34 \\
\hline Colocasia & 130 & 120 & 1 & nd & 1 & nd & 0.56 & 19 \\
\hline Amaranthus & 95 & 79 & 5 & nd & 8 & nd & 3.3 & 32 \\
\hline Brassica chinensis & 31 & 54 & $<1$ & nd & 1 & 8 & 1.2 & 7.4 \\
\hline Brassica nigra & 14 & 58 & $<1$ & $<1$ & $<1$ & 12 & nd & nd \\
\hline Brinjal & 110 & 76 & 2 & nd & nd & nd & nd & nd \\
\hline Tomato & 13 & 36 & traces & $<1$ & 1 & traces & 2.5 & 1.3 \\
\hline French bean & 27 & 54 & 1 & trace & 4 & $<1$ & 0.72 & 0.78 \\
\hline
\end{tabular}

Table 5: Phytochemical flavonols, carotenoids and antioxidant properties of some vegetables.

\author{
nd: not detectable.
}

Dry matter in the boiled water treated African wild cocoyam (BWTAWC) and cold water treated African wild cocoyam (CWTAWC) decreased from $64 \%$ (control) to 43 and $52 \%$, respectively after 9 days of soaking (Table 6). Crude protein was increased by $0.3 \%$ and $0.6 \%$ in BWTAWC by soaking over 6 and 9 days, respectively. CWTAWC showed an increase of $0.1,0.5$, and $1.1 \%$ of crude protein by soaking of 3, 6, and 9 days, respectively. Given the importance of dietary habit and food components to health, the provision of phytochemicals and antioxidant information of a range of foods is vital to support the future work in assessing the protective status of people from chronic degenerative disorders [57]. Food-based approaches would be essential for sustainable solutions to combat the alarming prevalence of chronic cancer, coronary heart diseases and diabetes.

\begin{tabular}{|l|c|c|c|c|c|}
\hline \multirow{2}{*}{ Component } & \multirow{2}{*}{ Treatment } & \multicolumn{4}{|c|}{ Period (days) } \\
\cline { 3 - 6 } & & 0 & 3 & 6 & 9 \\
\hline \multirow{2}{*}{ rry matter } & Hot water & 64.0 & 56.0 & 49.0 & 43.0 \\
\cline { 2 - 6 } & Cold water & 64.0 & 60.0 & 57.0 & 52.0 \\
\hline \multirow{2}{*}{$\begin{array}{l}\text { Crude } \\
\text { protein }\end{array}$} & Hot water & 4.70 & 4.70 & 5.00 & 5.30 \\
\cline { 2 - 6 } & Cold water & 4.70 & 4.80 & 5.00 & 5.80 \\
\hline \multirow{2}{*}{ Crude Fibre } & Hot water & 20.7 & 14.0 & 13.0 & 11.0 \\
\cline { 2 - 6 } & Cold water & 20.7 & 20.9 & 18.5 & 18.2 \\
\hline \multirow{2}{*}{ Ether extract } & Hot water & 6.50 & 4.90 & 4.20 & 3.93 \\
\cline { 2 - 6 } & Cold water & 6.50 & 6.10 & 5.60 & 5.00 \\
\hline \multirow{2}{*}{ Ash } & Hot water & 9.00 & 13.00 & 12.00 & 11.00 \\
\cline { 2 - 6 } & Cold water & 9.00 & 12.00 & 10.00 & 8.00 \\
\hline \multirow{2}{*}{$\begin{array}{l}\text { Gross Energy } \\
\text { (mcal/kg) }\end{array}$} & Hot water & 4.28 & 4.11 & 3.85 & 3.66 \\
\cline { 2 - 6 } & Cold water & 4.28 & 4.23 & 4.15 & 4.03 \\
\hline
\end{tabular}

Table 6: Proximate composition (g/100g) of boiled and cold water treated African wild cocoyam.

\section{Traditional uses}

The pressed juice of the colocasia petiole is styptic, and may be used to arrest arterial hemorrhage. It is used in ear ache and otorrhoea (discharge from ear), and also as stimulant and rubefacient and also in internal hemorrhages [33]. Leaf juice is stimulant, ex- pectorant, astringent, appetizer, and otalgia. Juice of the corm is used in cases of alopecia (baldness). Taro corms were used as a remedy for body ache. The juice extracted from the petioles with salt is used as an absorbent in case of inflamed glands and buboes i.e. swelling of the lymph nodes. Cooked vegetable contains mucilage and found to be an effective nervine tonic. Decoction of the peel is given as a folk medicine to cure diarrhea, increases body weight, prevents excessive secretion of sputum in asthamatic individuals. It acts as a laxative, demulcent, anodyne, galactagogue and is used in case of piles and congestion of the portal system; also used as an antidote to the stings of wasps and other insects. Kaulau, a traditional Polynesian desert known as coconut pudding in which, boiled dasheen is mixed with coconut milk and brown sugar. Taro corms are also used in the preparations of burger, bread, flakes, chips, flour, cookies, ice-cream, etc. Taro leaves used to prepare soups, pakore in some parts of coastal south India.

Starch derived from taro corm is unique because of its very small granular size $(1-5 \mu)$, significantly smaller than corn or wheat [25]. The combination of small granules and high solubility of dietary fibre content makes taro corm a good source of carbohydrate for extruded special products such as infant weaning diets and low glycemic index foods [24]. Taro corm has high contents of $\mathrm{K}$ and $\mathrm{Mg}$, ranges from $2251-4143$ and $118-219 \mathrm{mg} / 100 \mathrm{~g}$, and is a good source of water soluble vitamins as compared to other tropical roots. Taro corm is an important staple food in West Africa, also an excellent energy supplier [23], source of carbohydrate for diabetics and for those with gastrointestinal disorders [36].

In the Indian subcontinent both the roots and leaves are used for human consumption. In Karnataka state, they are used to make Patrode. In Kerala state, the leaves are used to make chembila curry, and the roots are used in chembupuzhukku, a traditional accompaniment to Kerala congee. The stem and root are also used in the preparation of Ishtu and Moru curry. In Tamil Nadu, it is boiled, peeled and fried and used as a side-dish with rice. In Andhra Pradesh, the roots are boiled, peeled, and fried as an entree with rice, or they may be boiled along with a gravy called "Pulusu", and 
the leaves are also used. In Nagaland, the leaves are dried, powdered, kneaded into a dough and baked into biscuits that are burnt and then dissolved in boiled water before being added into meat dishes to create a thick, flavoured dry gravy.

\section{Colocasia as a feed ingredient}

It is common practice for farmers in rural areas of Cambodia, north east India, Burma, Thailand, and Vietnam to keep a few local or crossbred pigs in a scavenging system with supplementation of locally available resources, such as rice bran, broken rice, kitchen waste, banana stems, water spinach and other water plants. The live weight gain is low, probably because of the poor quality of the feed, parasite infection and other diseases. In contrast, in the commercial farms the diets are usually based on soybean, cereals and fishmeal. However, this strategy is not appropriate for small farmers because of the high cost of conventional feed ingredients. The proteins in the leaves of many plants, being composed mostly of enzymes necessary for the growth of plant tissue, have an amino acid balance that resembles the "ideal" protein [42]. They should therefore be suitable to replace the fish meal and soybean meal used in commercial balanced feeds.

Taro is used for feeding livestock in all the tropical countries including Vietnam. Taro is a common plant grown or developing naturally near the houses, in the forests, ponds, streams and canals but farmers rarely fed taro to their pigs because of the itchiness [10]. Other researchers also evaluated the use of wild taro (Colocasia esculenta) for rearing crossbred pigs $[11,18]$. The constraints in taro leaves are the anti-nutritional factors, such as cyanogenic glycosides, trypsin inhibitors, mimosine, goitrogens, oxalic acid, tannins and saponins [35]. From studies on the nutritive value of tropical leaves for pigs [28], concluded that tropical tree leaves offer a variable amount of proteins that are well balanced in essential amino acids but not well digested by pigs.

The highest dry matter (DM) intake was recorded for treatment FM-TS (Taro leaf silage + fish meal + palm syrup + rice bran) and lowest for TS (Taro leaf silage + palm syrup + rice bran). The reason why the TS pigs were unable to consume the same amount of DM as those on FM-TS may have been the more voluminous nature (bulkiness) of this diet, while on treatment FM (Fish meal + palm syrup + rice bran) it appeared that the problem was the poor acceptability of the mixed ingredients [6]. Bulkiness is said to be due to the swelling of hydrated fibre and the final volume depends on fibre composition and structure. Intake of Xanthosoma leaves by sows were twice as high when these were fed dry compared with the fresh state, but that the water-holding capacity (WHC) was the same for both [28]. They considered that WHC alone could not explain the effects of bulkiness. Pigs fed ground sun-dried leaves of taro consumed more DM than when fed ensiled leaves [11]. The growth performance of pigs fed sugar palm syrup and rice bran was better when fish meal and ensiled taro leaves provided equal proportions of supplementary protein than when fish meal or ensiled taro leaves were the only supplements [38]. However, on the best treatment the growth rate and feed conversion were only some $50 \%$ of the genetic potential of the pigs for these traits.

\section{Taro meal as a feed ingredient in poultry}

Poultry birds consumed higher proportion of boiled taro have gained higher weight due to heat treatment of boiling, while birds consumed lower in raw taro due to toxic effect of unboiled cocoyam [1]. This is in line with the report by [3], indicating that boiling was more effective than sun drying alone in reducing the level of anti-nutritional factors (phytate, oxalate, tannins and saponin). The low daily feed intake in the control as compared with the other treatment levels of cocoyam meal inclusion in boiled taro could be due to higher energy in maize (control) diet. This agrees with the finding of [50] that the inability of the birds to extract required nutrients from the feed because of the effects of anti-nutritional factors which reduced feed digestibility and utilization.

It was observed that poorest feed/gain value in the ration with uncooked cocoyam which could have been due to high oxalate content of the ration [2]. Average cost of daily feed intake significantly decreased with increase in the level of cocoyam meal, inclusion in raw sundried taro. The lowest cost of daily feed intake was observed in $100 \%$ level of cocoyam meal in raw sundried taro. This was due to reduced feed intake, which indicates economic implications on the level of cocoyam inclusion in the diet. Generally, the cost of production decreases with increase in cocoyam meal. Proper processing of cocoyam meal will effectively replace maize at $25 \%$ (raw sundried) and $50 \%$ (boiled sundried) as a major source of energy in the diets of broiler finishers, however, use of cocoyam as substitute for maize is much more economical [5]. In comparison with levels of antinutritional factors in taro meal, the raw sundried cocoyam has significantly higher toxicants than the boiled cocoyam, because the cooking/boiling destroyed the toxicants to a large extent.

\section{Taro foliage on growth performance of ducks}

Good dietary balance amino acids are necessary for all monogastric livestock species. However, due to the increasing oil price and the competition with human demands, local feed resources are a good alternative in terms of convenience and maximum net profit. Recent studies have shown that expensive feedstuffs can be replaced by alternative cheap ingredients without reducing the feed value. The dry matter and crude protein intake by the common ducks were significantly increased, which offered by basal diet with different feeding levels $(3,4,5,6$ and $7 \%$ of BW) of taro leaves [20]. The mineral as well as vitamin content of the fresh taro leaves can meet the demand of ducks. Growth performance of ducks is poorer if they consume high amount of bulky and fibre rich feeds than the ducks fed with molasses substituted for broken rice and rice bran at 15 or $30 \%$ in the diets. There was a relationship between the percentage of taro leaves intake and the length of caecum as well as the weight of abdominal fat. Consumption of more taro leaves led to storing of less fat and the longer caecum. The fibrous bulk in the digestive tract could be the reason for the increase in caecum length. Taro foliage can be supplemented to local feed resources for common ducks to bring economic benefits for small holders. 
Growth rates of ducks were the same over a range of feed ratios of rice bran and taro silage from 80:20 to 40:60 and it was found $8 \%$ higher when the feeds were given as a mixture rather than separately [19]. Calcium oxalate in taro leaf-stem silage was lower than in fresh taro leaves. There was a positive effect on carcus quality (lower abdominal fat) from supplementing rice bran with taro silage. Ensiling process applied in forages should lead to an increase in the conc. of metabolizable energy in the diets, and to improve the growth performance rate and feed conversion. Ensiled taro foliage (leaves + stems) has relatively high nutritive value. The fresh taro leaves had a negative impact on the abdominal fat weight. The increase in caecum length in response to increase in dietary fiber is linear. The caecum in birds is mainly contributes to fibre digestion, it is a site for the breakdown and fermentation of cellulose that depends on microbial degradation. Similar results were observed by [26], in which the cassava leaf meal had an interaction with the weight and length of small intestine and caeca. This indicates that ducks would develop larger intestines, allowing more rapid digestible passage and higher absorption efficiency. Ensiling the combined leaf and stem of Xanthosoma was simpler process than ensiling leaf alone [43]. When leaves are ensiled alone a source of fermentable carbohydrate (Sugarcane juice) has to be added. However, the stem contains appreciable amount of soluble sugars, and thus there is no need for an additive when the leaves and stems were ensiled together.

\section{Ensiling taro leaves with sugarcane molasses}

Ensiling is the preservation of forage (crop residue or by-product) of high moisture content based on lactic acid fermentation under anaerobic conditions. The $\mathrm{pH}$ values decreased with time of ensiling and level of molasses added [29]. The concentration of $\mathrm{NH}_{3}-\mathrm{N}$ was increased with the time of ensiling (Table 7). After ensiling for 28 days with $4 \%$ molasses added, oxalate concentration was reduced from 2.20 to $0.30 \%$ of $\mathrm{DM}$, a reduction of $86 \%$. It was observed that ensiling Alocasia macrorrhiza leaves with rice bran and molasses reduced the calcium oxalate content by $79 \%$ [54]. The proportion of DM increased with the increasing level of molasses in comparison to fresh foliage.

\begin{tabular}{|l|c|c|c|c|c|}
\hline \multicolumn{1}{|c|}{ Constituent } & $\mathbf{0}$ days & $\mathbf{7}$ days & $\mathbf{1 4}$ days & $\mathbf{2 1}$ days & $\mathbf{2 8}$ days \\
\hline $\mathrm{pH}$ & 6.50 & 5.80 & 4.70 & 4.50 & 4.50 \\
\hline $\mathrm{DM}, \%$ & 22.0 & 24.0 & 20.6 & 20.8 & 20.9 \\
\hline $\mathrm{NH}_{3}-\mathrm{N}, \mathrm{mg} / \mathrm{kg} \mathrm{DM}$ & 236 & 908 & 879 & 906 & 1006 \\
\hline $\mathrm{NH}_{3}-\mathrm{N}$ in total N, \% & 0.95 & 3.42 & 3.16 & 3.18 & 3.49 \\
\hline
\end{tabular}

Table 7: Effect of ensiling time on chemical composition of ensiled taro leaves.

Increase in the conc. of $\mathrm{NH}_{3}-\mathrm{N}$ during the first 7 days of ensiling was due to breakdown of protein to amino acids, amines and ammonia as a result of relatively high $\mathrm{pH}$. After 7 days there was no further increase in $\mathrm{NH}_{3}-\mathrm{N}$ concentration [35]. Reduction of $\mathrm{NH}_{3}-\mathrm{N}$ due to addition of molasses was probably because the higher conc. of molasses the faster was the reduction in the $\mathrm{pH}$ of silage (Table 8). Proportion of water extractable $\mathrm{N}$ was increased by more than
$50 \%$ due to addition of molasses. A level of $4 \%$ molasses and ensiling for a period of 14 - 21 days appeared to be most appropriate for ensiling taro leaves, as determined by $\mathrm{pH}$, ammonia and oxalic acid conc.

\begin{tabular}{|l|c|c|c|c|}
\hline Constituent & $\mathbf{0}$ & $\mathbf{2}$ & $\mathbf{4}$ & $\mathbf{6}$ \\
\hline $\mathrm{pH}$ & 5.90 & 5.40 & 4.80 & 4.70 \\
\hline $\mathrm{DM}, \%$ & 22.2 & 20.6 & 21.4 & 22.5 \\
\hline $\mathrm{NH}_{3}-\mathrm{N}, \mathrm{mg} / \mathrm{kg} \mathrm{DM}$ & 989 & 863 & 689 & 60 \\
\hline $\mathrm{NH}_{3}-\mathrm{N}$ in total N, \% & 3.53 & 3.05 & 2.55 & 2.24 \\
\hline
\end{tabular}

Table 8: Effect of molasses level (\%) on chemical composition of ensiled taro leaves at 28 days of ensiling.

\section{Pharmacological properties}

Acute and chronic liver diseases constitute a global concern, but medical treatments for these diseases are often difficult to handle and have limited efficacy. Therefore, considerable efforts to obtain useful herbal medicines from medicinal plants for a wide variety of clinical conditions are currently underway [37]. Recently, natural plants have received much attention as sources of biologically active substances including antioxidants. Numerous studies have been carried out on plants, vegetables and fruits because they are rich sources of antioxidants, such as vitamin A, vitamin C, Vitamin E, carotenoids, polyphenolic compounds and flavonoids which prevent free radical damage, reducing risk of chronic diseases. Antioxidants are substances that delay or prevent the oxidation of cellular oxidizable substrates. They exert their effect by scavenging reactive oxygen species, activating a buttery of detoxifying proteins or preventing the generation of reactive oxygen species [49].

\section{Hypoglycemic property}

Anti-diabetic action of colocasia plant was reported by [22]. They investigated carbohydrate digestion and intestinal ATPases in streptozotocin-induced diabetic rats fed for 4 weeks with the extract of the plant or commercial linamarin. Rats fed commercial linamarin had significantly lower blood glucose level compared to the diabetic rats fed normal diet. Feeding of commercial linamarin to diabetic rats significantly decreased the activity of intestinal amylase compared to normal rats. Plant extract or linamarin increased the activities of intestinal disaccharides compared to diabetic rats fed normal diet. Plant extract/linamarin supplementation increased the $\mathrm{Na}^{+} / \mathrm{K}^{+}$ATPase activity, indicated that colocasia possess hypoglycemic activity which may be due to its cyanoglucoside content.

\section{Antifungal activity}

Antifungal activity of taro was evaluated by [58] and found recombinant CeCPI protein of the plant had toxic effect on mycelium growth of phytopathogenic fungi by exhibiting strong cysteine protease inhibitory activity.

\section{Anti-cancer action}

In vitro anti-cancer effect of taro on colonic adenocarcinoma cells [9]. The plant enhanced the proliferation of normal mouse splenocyte control cells, suggesting that colocasia is not simply 
toxic all cells but even has a positive immunostimulatory role. The plant showed the anticancer action by two distinct mechanisms: one, by inducing apoptosis (i.e. process of programmed cell death) within colon cancer cells; and the second, by non-specifically activating lymphocytes, which, in turn, can lyse cancerous cells.

\section{Hypolipidemic effect}

Ethanolic extract of taro plant containing the compounds like monogalactosyldiacyl glycerols and digalactosyl diacylglycerols showed $28-67 \%$ inhibitory activities at a conc. of $300 \mathrm{mg} / \mathrm{ml}$ for inhibition of human lanosterol synthase to suppress cholesterol biosynthesis [46].

\section{Anti-inflammatory activity}

Anti-inflammatory activity of ethanolic extract of leaves of taro in Wistar rats by inhibiting the leukocyte migration along with reduced pleural exudates and granuloma weight [47], thus the results indicated that ethanolic extract produced significant antiinflammatory activity.

\section{Neuropharmacological activities}

Neuropharmacological activities of hydroalcoholic extract of taro leaves in Wistar albino rats was reported by [41]. The extract $\left(100,200\right.$, and $\left.400 \mathrm{mg} \mathrm{kg}^{-1}\right)$ showed a significant reduction in the duration of immobility of Swiss albino mice. The plant extract at 50 and $100 \mathrm{mg} \mathrm{kg}^{-1}$ was found to produce a significant reduction in motor coordination and prolongation of thiopental-induced sleeping time. Thus, it indicated that plant possesses various neuropharmacological activities such as anti-depressant, anxiolytic, sedative, and smooth muscle relaxant activity. Colocasia contains various biologically active phyto-constituents such as flavonoids, sterols, glycosides, and other micronutrients and it can exploit in the medicinal and pharmaceutical field.

\section{Health benefits of taro}

- Taro corms have more calories than potatoes. $100 \mathrm{~g}$ provides 112 calories. Their calories mainly comes from complex carbohydrates known as amylose and amylopectin.

- Taro corms contain very low fats and protein than in cereals and pulses. Their protein levels are equivalent to that of other tropical food sources like yam, cassava, potato, banana etc.

- $\quad$ The corms are free from gluten. They feature high quality phyto-nutrition profile comprising of dietary fiber, and antioxidants in addition to moderate proportions of minerals, and vitamins.

- It is one of the finest source dietary fibers; $100 \mathrm{~g}$ flesh provides $4.1 \mathrm{~g}$ or $11 \%$ of daily-requirement of dietary fiber. Together with slow digesting complex carbohydrates, moderate amounts of fiber in the food helps gradual rise in blood sugar levels.

- Taro leaves as well as yellow-fleshed roots have significant levels of phenolic flavonoid pigment antioxidants such as ßcarotenes, and cryptoxanthin along with vitamin A, iron and folic acid, which protects against anemia [51]. $100 \mathrm{~g}$ fresh taro leaves provides 4825 IU or $161 \%$ of RDA of vitamin A. Altogether, these compounds are required for maintaining healthy mucus membranes, skin and vision. Consumption of natural foods rich in flavonoids helps to protect from lung and oral cavity cancers.

- The major groups of phytochemicals that may contribute to the total antioxidant capacity (TAC) of plant foods include polyphenols, carotenoids and the traditional antioxidant vitamins such as vitamin $\mathrm{C}$ and vitamin $\mathrm{E}$.

- $\quad$ Phytochemicals and vitamins present in plant foods having positive effects on the health of consumers and need further investigation.

Nutritional value of colocasia leaf rolls (patroraas) stuffed with flours of cereals (rice and maize), and legumes (soybean, bengalgram, and blackgram) in various combinations was studied [48] (Table 9). The rolls prepared with legumes were nutritionally and organoleptically superior to the rolls prepared with cereals.

\begin{tabular}{|l|c|c|c|c|c|}
\hline $\begin{array}{c}\text { Protein } \\
\text { source }\end{array}$ & $\begin{array}{c}\text { Crude pro- } \\
\text { tein (\%) }\end{array}$ & $\begin{array}{c}\text { Crude } \\
\text { fat(\%) }\end{array}$ & $\begin{array}{c}\text { Crude } \\
\text { fiber (\%) }\end{array}$ & $\begin{array}{c}\text { Carbohy- } \\
\text { drates (\%) }\end{array}$ & $\begin{array}{c}\text { Energy } \\
\text { (Kcal) }\end{array}$ \\
\hline Rice & 4.09 & 20.83 & 2.41 & 73.13 & 459 \\
\hline Maize & 6.58 & 22.47 & 3.56 & 68.45 & 454 \\
\hline Bengalgram & 12.86 & 22.94 & 3.23 & 61.34 & 456 \\
\hline Blackgram & 14.33 & 21.03 & 3.17 & 61.52 & 442 \\
\hline Soybean & 23.36 & 30.13 & 3.79 & 42.65 & 466 \\
\hline $\begin{array}{l}\text { Rice+ Soy- } \\
\text { bean (1:1) }\end{array}$ & 13.73 & 25.79 & 3.15 & 57.67 & 464 \\
\hline $\begin{array}{l}\text { Maize + } \\
\text { Soybean } \\
(1: 1)\end{array}$ & 14.97 & 26.61 & 3.68 & 55.24 & 462 \\
\hline $\begin{array}{l}\text { Bengalgram } \\
+ \text { Soybean } \\
(1: 1)\end{array}$ & 18.11 & 26.73 & 3.51 & 51.80 & 462 \\
\hline $\begin{array}{l}\text { Blackgram } \\
+ \text { Soybean } \\
(1: 1)\end{array}$ & 18.85 & 25.89 & 3.48 & 51.77 & 458 \\
\hline $\begin{array}{l}\text { CD } \\
\text { (P = 0.05) }\end{array}$ & 1.25 & 1.37 & 0.65 & 2.18 & 0.02 \\
\hline
\end{tabular}

Table 9: Nutritional evaluation of colocasia leaf rolls stuffed with different protein sources

Poi as a food substitute for infant allergies

In 1939 [4], was the first to suggest that poi being used as a substitute for people with allergies. It is interesting that in the United States, allergies are most often caused by corn and wheat, while in Japan, allergies are most often caused by rice [45]. During World War II, poi was used as a substitute for cereal or grain in Honolulu among soldiers experiencing allergy problems [12]. Food allergies most frequently afflict children [15] with cow's milk being the most common allergenic food for infants, followed by eggs, peanuts, tree nuts, and soybeans [7]. Poi is to be considered a substitute for soy milk in infants allergic to both soy and cow's milk was first reported by [14]. Cereals can also cause allergies in infants because they 
usually are the first semi-solid food consumed. The most common method of treatment for food allergies is the elimination of diet, in which the specific food is avoided or eliminated [53]. This approach can be difficult because not many alternative medical foods are available, and many infants develop allergies to the substitutes that are given [53]. Poi fed infants were tolerated allergies, and it may be regarded as a useful alternative when there is a family history of cereal allergy [44]. Poi may also be useful for people with celiac disease, who are allergic to the protein gluten in wheat. Although it has been suggested that the lack of gluten in poi makes it an ideal substitute for cereals in patients with celiac disease. This may be partially due to the rarity of this condition in Hawaii, as this condition more frequently afflicts Caucasians than Asians [21].

Ethanolic extract of colocasia (EECE) leaves for antidiabetic activity on blood glucose level and on the body weight in alloxan induced diabetic rats was evaluated by [27]. EECE $(100,200$ and $\left.400 \mathrm{mg} \mathrm{kg}^{-1}\right)$ and metformin (450 $\mathrm{mg} \mathrm{kg}^{-1}$ ) were administered orally in alloxan $\left(120 \mathrm{mg} \mathrm{kg}^{-1}\right.$, i.p.) induced diabetic rats. In acute oral toxicity (AOT 425) study, administration of EECE no mortality up to $5000 \mathrm{mg} \mathrm{kg}^{-1}$ was observed. The onset of reduction of blood glucose was observed at $4 \mathrm{~h}(96 \mathrm{mg} / \mathrm{dl})$, peak at $6 \mathrm{~h}(120 \mathrm{mg} / \mathrm{dl})$ but antihyperglycaemic effect waned at $24 \mathrm{~h}$ (Table 10). EECE (100, 200 and $400 \mathrm{mg} \mathrm{kg}^{-1}$ ) as well as metformin showed significant reduction of blood glucose levels at 2, 4, and $6 \mathrm{~h}$. The antihyperglycaemic activity of EECE may be due to presence of several bioactive antidiabetic principals, thus EECE possess antihyperglycaemic activity. In sub acute study, maximum reduction in blood glucose was observed (174.34 mg/dl) at the dose of $400 \mathrm{mg} \mathrm{kg}^{-1}$ on $14^{\text {th }}$ day (Table 11). EECE prevented further loss of body weight. Maximum reduction in blood glucose level was observed on $14^{\text {th }}$ day in the diabetic rats treated with $\operatorname{EECE}\left(100,200\right.$ and $\left.400 \mathrm{mg} \mathrm{kg}^{-1}\right)$. Metformin treated animals showed maximum reduction in blood glucose level on $14^{\text {th }}$ day. EECE treated doses showed improvement in body weight indicating its beneficial effect and it is able to reduce hyperglycaemia. Preliminary Phytochemical investigation revealed the presence of alkaloids, flavonoids, saponins and tannins as the major constituents in the ethanol extract. These results suggest that EECE (400 $\mathrm{mg} \mathrm{kg}^{-1}$ ) showed antihyperglycaemic activity in alloxan induced diabetic rats.

\begin{tabular}{|l|c|c|c|c|c|}
\hline \multirow{2}{*}{$\begin{array}{c}\text { Treatment (mg/ } \\
\text { kg p.o.) }\end{array}$} & \multicolumn{5}{|c|}{ Blood glucose level (mg/dd) } \\
\cline { 2 - 6 } & $\mathbf{0 ~ h r}$ & $\mathbf{2 h r}$ & $\mathbf{4} \mathbf{~ h r}$ & $\mathbf{6 ~ h r}$ & $\mathbf{2 4} \mathbf{~ h r}$ \\
\hline Negative control & $276 \pm$ & $279 \pm$ & $283 \pm$ & $295 \pm$ & $299 \pm$ \\
& 12.3 & 5.3 & 12.3 & 14.4 & 12.4 \\
\hline Metformin (450) & $348 \pm$ & $312 \pm$ & $229 \pm$ & $198 \pm$ & $237 \pm$ \\
& 25.1 & 8.8 & 12.6 & 13.9 & 12.9 \\
\hline EECE (100) & $320 \pm$ & $303 \pm$ & $248 \pm$ & $226 \pm$ & $251 \pm$ \\
& 15.6 & 12.6 & 10.3 & 17.4 & 14.1 \\
\hline EECE (200) & $323 \pm$ & $307 \pm$ & $244 \pm$ & $221 \pm$ & $247 \pm$ \\
& 17.5 & 10.0 & 10.4 & 19.4 & 13.0 \\
\hline EECE (400) & $330 \pm$ & $310 \pm$ & $234 \pm$ & $210 \pm$ & $246 \pm$ \\
& 16.4 & 10.2 & 8.9 & 18.0 & 13.9 \\
\hline
\end{tabular}

Table 10: Effect of ethylene extract of Colocasia esculanta (EECE) on blood glucose level in alloxan-induced diabetic rats (acute study).

\begin{tabular}{|l|c|c|c|}
\hline \multirow{2}{*}{$\begin{array}{c}\text { Treatment } \\
\text { (mg/kg p.o.) }\end{array}$} & \multicolumn{3}{|c|}{ Blood glucose level (mg/dl) } \\
\cline { 2 - 4 } & $\mathbf{0 ~ d a y}$ & $\mathbf{7 ~ d a y}$ & $\mathbf{1 4 ~ d a y ~}$ \\
\hline Negative control & $276 \pm 12.3$ & $316 \pm 15.1$ & $332 \pm 11.2$ \\
\hline Metformin $(450)$ & $348 \pm 25.1$ & $199 \pm 11.2$ & $144 \pm 12.3$ \\
\hline EECE $(100)$ & $320 \pm 15.6$ & $242 \pm 18.5$ & $188 \pm 9.4$ \\
\hline EECE $(200)$ & $323 \pm 17.5$ & $224 \pm 17.7$ & $168 \pm 15.0$ \\
\hline EECE $(400)$ & $330 \pm 16.4$ & $220 \pm 18.1$ & $156 \pm 12.8$ \\
\hline
\end{tabular}

Table 11: Effect of ethylene extract of Colocasia esculanta (EECE) on blood glucose level in alloxan-induced diabetic rats (Sub acute study).

Influence of processing methods on quality

A major constraint to livestock production is the lack of animal feed resources. Many by-products and forages are not available throughout the year and therefore need to be stored with appropriate processing methods. Presence of calcium oxalate in taro causes irritation on contact. Density of calcium oxalate crystals in corms increases rapidly in the early stage, then decreases in older and larger corms. Corms can be cooked for human consumption, but Cambodian farmers rarely use taro petioles and leaves for animal feeding. In order to reduce the itchiness of taro caused by the calcium oxalate, most farmers boil taro before feeding it to their pigs or add sugar palm syrup after boiling, while others apply salt, frying or sun drying [39]. Ensiled forages are a good feed source for animals, as monogastrics can digest all enzymatically digestible components in the small intestine and fibrous materials are fermented quickly in the large intestine then easily absorbed as nutrients.

Taro leaves, or the mixture of petioles and leaves, are harvested and chopped into small pieces. Then, the taro pieces are partially sun-dried to reduce the moisture content and packed tightly into plastic bags or containers. The bags should be sealed tightly to prevent contamination by air. Taro mixed with rice bran and salt (10 $\mathrm{kg}$ rice bran, $0.5 \mathrm{~kg}$ salt and $89.5 \mathrm{~kg}$ taro leaves), and the silage was stored in normal temperature for 30 days before being used, because of to reduce calcium oxalate content [11]. Other additives can be used to stimulate the fermentation of bacteria and improve the palatability, such as molasses and sugar palm syrup. Fibre content in taro leaves reduced by ensiling. It is apparent that the ensiled taro foliage (leaves plus stems) has a relatively high nutritive value. Ensiling the combined leaf and stem of new cocoyam was a simpler process than ensiling only the leaf [43]. When leaves were ensiled alone a source of fermentable carbohydrate (sugar cane juice) had to be added. However, it was found that the stem contained appreciable amounts of soluble sugars, and thus there was no need for an additive when the leaves and stems were ensiled together because of stems of taro contained high levels of soluble sugars (up to $40 \%$ in the DM).

\section{Toxicity in humans by ingestion of colocasia}

It was reported that the entire plant (leaf, stem, and root) is toxic [31]. If ingested raw, it show intense burning and irritation of lips, mouth, tongue, and throat; vomiting; diarrhea (uncommon); base of tongue swells and can be fatal if swelling is large enough 
to block the air passage of the throat; death by asphyxiation. It contains calcium oxalate crystals which are needle-shaped and arranged in compact bundles. When chewed the crystals are ejected from specialized explosive ejector cells. Needles get lodged in the lining of the mouth, tongue, and throat leading to local inflammatory reactions. Calcium oxalate crystals-Raphides, oxalate is an unstable salt of oxalic acid, soluble in water, alcohol, and ether. It was composed of: 2 carboxyl groups, creates dangerous free-radicals in the body. Needle fibers induce inflammatory response and edema in oral cavities and mucous membranes. Calcium oxalate dissolves in the stomach to form oxalic acid, more readily absorbed into the blood circulation system. It is very dangerous if ingested in large amounts. Oxalic acid can bind with calcium in the body resulting in hypocalcaemia and it can lead to muscle cramps, hypotension, bradycardia, and cardiac arrhythmia. Binding of oxalic acid with calcium in the body can induce crystallization of calcium oxalate. Calcium oxalate causes kidney stones and it can lead to liver and kidney failure and cause permanent damage.

How to reduce the toxic effects of calcium oxalate

Calcium chloride and calcium gluconate should be administered for large ingestion of plant because these compounds act by replenishing the $\mathrm{Ca}$ in the circulation, thus reducing the toxic effects. Providing extra Ca reduces the toxic danger of the free oxalic radicals [52]. As a precaution, colocasia should be eaten with milk or other foods rich in calcium. Oxalate crystals in plant cause extreme inflammatory immune response which may lead to death. Minor gastrointestinal distresses to serious heart conditions can be caused by low calcium levels due to oxalic acid ingested from Colocasia. Kidney stones, major organ failure, and tissue damage can also result from deposits of calcium oxalate, formed by oxalic acid binding calcium in the body. Colocasia should never be eaten raw. Proper cooking methods and precautions should be followed closely. Calcium should be taken appropriately when ingesting. Taro must be the most delicious dish in the world.

\section{Conclusion}

Colocasia is a highly potential and remunerative crop and is being grown across various regions in the world. Making awareness to various clientele groups is essential about its diversified uses, richness in phyto-nutrients, as an ingredient in pharmaceutical industries as well as feed substitute for livestock. Consumption of taro in large amounts causes kidney stones, major organ failure, and tissue damage as resulted from deposits of calcium oxalate in human beings. Taro must be most delicious dish in the world by following proper cooking methods and precautions in order to reduce the oxalate content. Since taro is widely adaptable for cultivation under varied agro-climatic conditions, it is having immense potential for income generation, livelihood and nutritional security.

\section{Bibliography}

1. Abdulrashid M and Agwunobi LN. "Taro Cocoyam (Colocasia esculenta) Meal as Feed Ingredient in Poultry". Pakistan Journal of Nutrition 8.5 (2009): 668-673.
2. Adama TZ and Ayanwale BA. "Performance of rabbits fed Xanthosoma sagittifolium and Luffa aegyptica". Proceedings of 4th Annual Conference of Animal Science Association of Nigeria, Sept. 14-16, Nigeria (1999): 140-142.

3. Agwunobi LN., et al. "Studies on the use of Colocasia esculenta (taro cocoyam) in the diets of weaned pigs". Tropical Animal Health and Production 34.3 (2002): 241-247.

4. Alverez WC. "Problems of maintaining nutrition in the highly food-sensitive person". The American Journal of Digestive Diseases 5 (1939): 801-803.

5. Anigbogu MM. "Effect of Replacing Corn with Taro (Colocasia asculenta L.) Meal on the Live weight, Dressing Percentage and Cut-up yield and Litter Condition of Broiler Chicks". Proceeding of 2nd Annual Conference of Animal Science Association of Nigeria, Lagos (1997).

6. Bach Knudsen KE. "The nutritional significance of dietary fibre analysis". Animal Feed Science and Technology 90 (2001): 3-20.

7. Bock SA and Martin M. "The incidence of adverse reactions to foods-a continuous study”. Journal of Allergy and Clinical Immunology 71: 98.

8. Bradbury JF. "Identification of cultivable bacteria from plants and plant tissue cultures by use of simple classical methods". Acta Horticulturae 225 (1983): 27-37.

9. Brown AC., et al. "The anti-cancer effects of poi (Colocasia esculanta) on colonic adenocarcinoma cells In vitro". Phototherapy Research 19 (2005): 767-771.

10. Buntha P., et al. "Effect of Taro (Colocasia esculenta) leaf silage as replacement for fish meal on feed intake and growth performance of crossbred pigs". Livestock Research for Rural Development 20 (2008).

11. Chhay Ty., et al. "Intake, digestibility and N retention by growing pigs fed ensiled or dried Taro (Colocasia esculenta) leaves as the protein supplement in basal diets of rice bran/broken rice or rice bran/cassava root meal". Livestock Research for $\mathrm{Ru}$ ral Development 19 (2007).

12. Derstine V and Rada EL. "Some dietetic factors influencing the market for poi in Hawaii". In: Agricultural Economics, Bulletin 3 Hawaii: University of Hawaii Agricultural Experiment Station 3 (1952): 1-43.

13. FAO. "Food and Agriculture Organization of the United Nations Statistical Year Book published by FAO, Rome, Italy” (2018).

14. Feingold BF. "A vegetable milk substitute: taro". Journal of Allergy 13 (1942): 488.

15. Fries JH. "Peanuts: allergic and other untoward reactions". Annals of Allergy 48 (1982): 220-226. 
16. Fukumoto LR and Mazza G. "Assessing antioxidant and prooxidant activities and phenolic compounds". Journal of Agricultural and Food Chemistry 48 (2000): 3597-3604.

17. Ghiselli A., et al. "Total antioxidant capacity as a tool to assess redox status: critical view and experimental data". Free Radical Biological Medicine 29.1 (2000): 1106-1114.

18. Giang NT. "Taro (Colocasia esculenta) silage and water spinach as supplements to rice bran for growing pigs" (2008).

19. Giang NT. "Effect of taro (Colocasia esculanta) foliage on the performance of growing common ducks". M.Sc. Thesis submitted to Swedish University of Agricultural Sciences, Uppasala (2010).

20. Giang NT., et al. "Effect on the performance of common ducks of supplementing rice polishings with taro (Colocacia esculenta) foliage". Livestock Research for Rural Development 22 (2010).

21. Glaser J., et al. "Poi-its use as a food for normal, allergic and potentially allergic children". Annals of Allergy 25 (1967): 496500 .

22. Grindley BA., et al. "Carbohydrate digestion and intestinal ATPases in streptozotocin-induced diabetic rats fed extract of yam (Dioscorea cayenensis) or dasheen (Colocasia esculanta cv. Kaosiung no. 1)”. Planta Medica 221 (2002): 493-501.

23. Huang CC., et al. "Comparison of Taiwan paddy-and uplandcultivated taro (Colocasia esculenta L.) cultivars for nutritive values". Food Chemistry 102 (2007): 250-256.

24. Huang AS., et al. "Nutrient composition of Hawaiian taro corms and breadfruit". Journal of Food Composition and Analysis 13 (2000): 859-864.

25. Jane J., et al. "Physical and chemical studies of taro starches and flours". Cereal Chemistry 69 (1992): 528-535.

26. Khieu Borin., et al. "Digestibility and digestive organ development in indigenous and improved chickens and ducks fed diets with increasing inclusion levels of cassava leaf meal". Doctoral thesis No. 82 (2006).

27. Kumawat NS., et al. "Antidiabetic activity of ethanol extract of Colocasia esculenta leaves in alloxan induced diabetic rats". International Journal of PharmTech Research 2.2 (2010): 12461249.

28. Leterme P., et al. "Chemical composition, nutritive value and voluntary intake of tropical tree forage and cocoyam in pigs". Journal of Science of Food and Agriculture 85 (2005): 17251732.

29. Malavanh C., et al. "Ensiling leaves of Taro (Colocasia esculenta (L.) Shott) with sugar cane molasses". Livestock Research for Rural Development 20 (2008).
30. Marco DBF., et al. "Mechanisms of disease: antioxidants and atherosclerotic heart disease". New England Journal of Medicine 337.6 (1997): 408-416.

31. Medina A., et al. "Toxicity in Humans by Ingestion of Colocasia esculenta (Elephant Ear)". Biology (2007): 445.

32. Milner A. "Functional foods and health promotion". Journal of Nutrition 129 (1999): 1395-1397.

33. Namrata., et al. "Wild Edible Plants of Uttarakhand Himalaya: A Potential Nutraceutical Source". Research Journal of Medicinal Plant 5 (2011): 670-684.

34. Niba LL. "Processing effects on susceptibility of starch to digestion in some dietary starch sources". International Journal of Food Sciences and Nutrition 54 (2003): 97-109.

35. Ogle B. "Forage for pigs: nutritional, physiological and practical implication". Workshop-seminar "Forages for Pigs and Rabbits" MEKARN-CelAgrid, Phnom Penh, Cambodia, 22-24 August 2006 (2006).

36. Onwueme IC. "In The Tropical Tuber Crops, Yam, Cassava, Sweet Potato and Cocoyam". John Wiley and Sons, New York and Brisbane Toronto (1978): 199-227.

37. Patil BR and Ageely HM. "Antihepatotoxic activity of Colocasia esculenta leaf juice". International Journal of Advanced Biotechnology and Research 2 (2011): 296-304.

38. Pheng Buntha., et al. "Digestibility and nitrogen balance studies in pigs fed diets with ensiled taro (Colocasia esculenta) leaves as replacement for fish meal". M.Sc. Thesis, MEKARNSLU.

39. Pheng Buntha., et al. "Digestibility and nitrogen balance studies in pigs fed diets with ensiled taro (Colocasia esculenta) leaves as replacement for fish meal". Livestock Research for Rural Development 20 (2008).

40. Pellegrini N., et al. "Polyphenol content and total antioxidant activity of ViniNovelli (young red wines)". Journal of Agricultural and Food Chemistry 48.3 (2000): 732-735.

41. Prajapati R., et al. “Colocasia esculenta: A potential indigenous plant”. International Journal of Nutrition, Pharmacology, Neurological Diseases 1.2 (2011): 90-96.

42. Preston TR. "Forages as protein sources for pigs in the tropics". Workshop-seminar "Forages for Pigs and Rabbits" MEKARNCelAgrid, Phnom Penh, Cambodia (2006).

43. Rodríguez L and Preston TR. "A note on ensiling the foliage of New Cocoyam (Xanthosoma sagittifolium)". Livestock Research for Rural Development (2009): 11.

44. Roth A., et al. "Use of poi in the prevention of allergic disease in potentially allergic infants". Annals of Allergy 25 (1967): 501506. 
45. Rowe AH. "Elimination Diets and the Patient's Allergies". A Handbook of Allergy, 2nd ed. Philadelphia: Lea and Febiger (1944).

46. Sakano Y., et al. "Inhibition of human lanosterol synthase by the constituents of Colocasia esculenta (Taro)". Biological and Pharmaceutical Bulletin 28 (2005): 299-304.

47. Shah BN., et al. "The anti-inflammatory activity of the leaves of Colocasia esculenta". Saudi Pharmaceutical Journal 15 (2007): 3-4.

48. Singh P and Sharma HR. "Nutritional and organoleptic evaluation of Colocasia leaf rolls supplemented with different protein sources". Journal of Human Ecology 14 (2003): 467-469.

49. Sonia M and Mohamed D. "In vitro antioxidant activities of aloe vera leaf skin extracts". Journal de la SociétéChimique de Tunisie 10 (2008): 101-109.

50. Stevenson MH and Jackson N. "The nutritional value of dried cassava root meal in broiler diets". Journal of the Science of Food and Agriculture 34.1 (1983): 1361-1367.

51. Sukamoto LA. "Development of early maturing and leaf blight resistant cocoyam (Colocasia esculenta (L.)Schott) with improved taste". Proceedings of a final research coordination meeting organized by the joint FAO/IAEA division of nuclear techniques in food and agriculture and held in Pretoria, South Africa (2003): 19-23.

52. Tagwireyi D and Ball DE. “The management of Elephant's Ear poisoning". Human and Experimental Toxicology 20.4 (2001): 189-192.

53. Taylor SL. "Food allergies". Food Technology 43.11 (1985): 98102.

54. Tiep PS., et al. "Study on the use of Alocasia macrorrhiza (roots and leaves) in diets for crossbred growing pigs under mountainous village conditions in northern Vietnam". Workshopseminar "Forages for Pigs and Rabbits" MEKARN-CelAgrid, Phnom Penh, Cambodia (2006).

55. Vinson J., et al. "Phenol antioxidation quantity and quality in foods: fruit". Journal of Agricultural and Food Chemistry 49.11 (2001): 5315-5321.

56. Wolfe KWX and Liu RH. "Antioxidant activity of apple peels". Journal of Agricultural and Food Chemistry 51 (2003): 609614.

57. Worsely A. "Diet and hypertension in the Asia-Pacific region: a brief review". Asia Pacific Journal of Clinical Nutrition 10.2 (2001): 97-102.
58. Yang $\mathrm{AH}$ and Yeh KW. "Molecular cloning, recombinant gene expression, and antifungal activity of cystatin from taro (Colocasia esculenta cv. Kaosiung no. 1)”. Planta Medica 221 (2005): 493-501.

\section{Assets from publication with us}

- Prompt Acknowledgement after receiving the article

- Thorough Double blinded peer review

- Rapid Publication

- Issue of Publication Certificate

- High visibility of your Published work

Website: www.actascientific.com/

Submit Article: www.actascientific.com/submission.php Email us: editor@actascientific.com

Contact us: +919182824667 